\title{
Tværfaglighed som ideal og praksis - folkesundhedsvidenskabelige erfaringer i at uddanne på tværs af faggrænser
}

Annegrete Juul Nielsen, adjunkt, Institut for Folkesundhedsvidenskab, Københavns Universitet.

Signild Vallgårda, professor, Institut for Folkesundhedsvidenskab, Københavns Universitet.

\section{Reviewet artikel}

Uddannelsespolitisk fokuseres der i stigende grad på tværfaglighed. Nye uddannelser, som kombinerer flere discipliner, etableres, og tværfaglighed er ofte et kriterium for finansiering af forskningsprojekter. Tværfaglighed associeres af mange med attraktive egenskaber og muligheder som skræddersyede studieforløb, flerstrengede kompetenceprofiler, det bedste fra forskellige discipliner, ny innovativ viden $m$. $m$. Men kan tværfaglighed virkelig hoste det bedste fra alle verdner? Og hvad indebærer tværfaglighed egentlig? Den første del af artiklen diskuterer tværfaglighed ved at se nærmere på eksisterende definitioner af begrebet. Den anden del af artiklen ser nærmere på et konkret eksempel på hvordan tværfaglighed praktiseres på kandidatuddannelsen i Folkesundhedsvidenskab ved Københavns Universitet. Vi argumenterer for, at forskellige former for tværfaglighed skal ses som en ressource fremfor som et problem. Det springende punkt i dette argument er, at tværfagligheden bor gøres eksplicit fremfor at være implicit, da den ellers let bliver noget, vi overlader til de studerende at håndtere og praktisere. Det kan $f x$ gøres ved at gøre tværfaglighed til et læringsmål i relevante kurser og opgaver og ved, at underviserne overvejer og formidler, hvilken form for tværfaglighed de efterstræber.

\section{Introduktion}

Uddannelsespolitisk fokuseres der i stigende grad på tværfaglighed. Nye uddannelser, som kombinerer flere discipliner, etableres, og tværfaglighed er ofte et kriterium for finansiering af forskningsprojekter. Ministeren for området har udtrykt ønske om større fleksibilitet på universiteterne, sådan at de studerende kan kombinere fag fra flere uddannelser og gå fra en bacheloruddannelse i et fag til en kandidatuddannelse i et andet (Østergaard, 2012). De øgede krav om tværfaglighed begrundes med at arbejdsmarkedet ikke efterspørger én, men mange forskellige kompetencer hos 
kommende kandidater samt, at de studerende stiller krav om i større udstrækning at kunne præge indholdet af deres uddannelse (Københavns Universitet, 2009). Tværfaglighed har dog uddannelsespolitisk længe været et honnørord (Foster, 1999). Det associeres med attraktive egenskaber og muligheder som skræddersyede studieforløb, flerstrengede kompetenceprofiler, det bedste fra forskellige discipliner, ny innovativ viden m. m. (Newell, 1994; Lattuca, 2004, Ivanitskaya, 2002). Men når noget bare er godt, bedre og indlysende fordelagtigt, begynder spørgsmålene at melde sig hos de fleste forskere. For kan det virkelig passe, at man med tværfaglighed kan høste det bedste fra alle verdner? Er det tilstrækkeligt at sætte forskellige discipliner sammen, eller kræver tværfaglighed, at faggrænserne udviskes? Og hvilke særlige krav stiller tværfaglig undervisning til henholdsvis den studerende og underviseren? De politiske visioner om øget tværfaglighed synes med andre ord også at indebære en række udfordringer, som i mindre grad inddrages i lovprisningen af tværfaglighed (Davies \& Devlin, 2010). Gennem en diskussion af, hvordan tværfaglighed begrebsliggøres og praktiseres, vil vi med denne artikel $^{1}$ give nyt input til debatten om øget tværfaglighed.

Første del af artiklen diskuterer eksisterende definitioner og typologier om tværfaglig undervisning. I anden del tager vi udgangspunkt i et konkret eksempel på tværfaglighed, nemlig den tværfaglige kandidatuddannelse i Folkesundhedsvidenskab (FSV) på Københavns Universitet. Vi undersøger de konkrete måder, som tværfaglighed praktiseres på i et uddannelsesprogram som Folkesundhedsvidenskab. I den afsluttende del sammenholdes indsigterne fra de to dele. Her trækker vi også på vores egne erfaringer som tidligere studerende, studievejleder, studieleder og undervisere på en tværfaglig universitetsuddannelse.

\section{Fag og tværfaglighed}

For at kunne tale om tværfaglighed forudsætter det, at vi ved, hvad det er, der overskrides. Det vil sige, at implicit i begrebet om tværfaglighed er der også en definition af, hvad et fag er. Hvordan et fag eller en akademisk disciplin defineres eksisterer der ikke overraskende en lang række bud på. En traditionel definition af en disciplin er, at det et studieområde med egne teorier, metoder og indhold, hvis særegenhed er institutionelt anerkendt gennem eksistensen af institutter, programmer m.m. (Davies \& Devlin, 2010). En af begrænsningerne ved denne måde at definere en disciplin på er dog, at den ikke tager højde for, at et fag ikke er en historisk stabil størrelse, men noget der udvikler sig over tid og ofte rummer en flerhed af genstandsfelter, metoder og teorier. Et fags grænser er således ofte både permeable og historisk betingede. Aram (2004) har givet en definition, som forsøger at indfange dette: “[Disciplines are]

\footnotetext{
${ }^{1}$ Artiklen bygger på et pædagogisk projekt Annegrete Juul Nielsen udarbejdede som en del af adjunktpædagogikum.
} 
thought domains - quasi stable, partially integrated, semi-autonomous, intellectual conveniences - consisting of problems, theories and methods of investigation"(Aram 2004, s. 380 i: Davies and Devlin, 2010). Problemet med denne definition er, at den ikke hjælper os med at skelne mellem fag og tværfaglighed. Empirisk kan det iagttages, at en lang række (mono)fag i princippet kunne defineres som tværfaglige, da de inddrager forskellige videnskabsteoretiske ståsteder, fx positivistiske og konstruktivistiske, samt forskellige metodiske tilgange, fx kvantitative og kvalitative metoder. Det gælder fx fag som Psykologi og Historie. På samme måde kan det empirisk iagttages, at nogle fag over tid går fra en tværfaglig til en monofaglig identitet. Det vil sige, at det at betragte den samme problemstilling fra forskellige vinkler og metoder ophører med at betragtes som en tværfaglig tilgang og blot betragtes som (mono)fagets tilgang. Det gælder fx et fag som Statskundskab. Begrebsligt er det med andre ord vanskeligt at sætte en skarp grænse mellem fag og tværfaglighed. Konklusionen må derfor være, at det afgørende er, at vi definerer, hvad vi forstår ved vores begreber i den konkrete situation. I denne artikel bruger vi fagenes egen forståelse af sig selv som hhv. monofaglig eller tværfaglig til at skelne mellem monofag og tværfaglige fag.

\section{Hvad er tværfaglighed?}

Som begreb har tværfaglighed (på engelsk oftest 'interdisciplinarity') - eller tværvidenskabelig, interdisciplinær, flerfaglig, fagintegration osv. været omdiskuteret og genstand for mange forskellige udlægninger (Francks et al., 2007). De mange forskellige betegnelser er dog ikke alene et spørgsmål om, at kært barn har mange navne, men refererer også til, at der er forskellige kriterier og opfattelser af, hvornår undervisning, uddannelse eller forskning er tværfaglig (Spelt et al., 2009). Er det alle aktiviteter, hvor der deltager mere end et fag, eller er det kun aktiviteter, hvor forskellige fag mødes i en ny konstellation og vidensproduktion?

Francks et al. (2007) begrebsliggør, på baggrund af en række eksisterende definitioner, tværfaglighed som noget, der forener og integrerer viden og låner eller anvender redskaber fra forskellige discipliner. Youngblood (2007) introducerer en mere detaljeret definition, der skelner mellem tre stigende grader af tværfaglighed. Armstrong (1980, s. 53-54) går videre endnu og introducerer en typologi med 4 niveauer for tværfaglig undervisning, som er kendetegnet ved, at fagene har forskellige relationer bestemt af funktionsmæssige hensyn. En enkel definition finder vi hos Nielsen (1996), som opererer med to former for tværfaglighed i forbindelse med undervisning: Formel og funktionel tværfaglighed. Formel tværfaglighed indebærer, at der i undervisning arbejdes med samme emne i forskellige fag. Læringsforestillingen er, at studerende ved at arbejde parallelt med det samme emne i forskellige fag, selv vil danne synteser på tværs af fagene. Funktionel tværfaglighed definerer Nielsen som, når der i undervisning arbejdes med en integration af to eller flere fag i en faggræn- 
seoverskridende problemstilling. Læringsforestillingen er her, at de studerende ved at arbejde på denne måde trænes $i$ at integrere viden fra forskellige fag på nye måder. Nielsens typologi svarer til den, Spelt et al. (2009) laver mellem tværfaglig og flerfaglig (Spelt et al. 2009). Da tværfaglig og flerfaglig har mange andre betydninger, og vi til dette formål har brug for en enkel typologi, har vi i de følgende valgt at tage udgangspunkt i Nielsens skelnen mellem formel og funktionel (eller fagoverskridende) tværfaglighed.

Skelnen mellem forskellige former for tværfaglighed er ofte tæt knyttet til en normativ antagelse om, at jo mere faggrænserne udviskes (funktionel tværfaglighed), jo bedre en tværfaglighed er der tale om (Youngblood, 2007; Francks et al., 2007). Ifølge denne tradition er tværfaglighed for det første bedre end monofaglighed, og for det andet er funktionel tværfaglighed bedre end formel tværfaglighed (Cook-Sather \& Shore, 2007). Vi mener dog, at man kan stille spørgsmålstegn ved, om målet med tværfaglighed altid bør være fagoverskridelse. Tværtimod kan den normative tilgang til tværfaglighed, som præger en del af litteraturen, være med til at forhindre, at der praktiseres forskellige former for tværfaglighed på uddannelser som fx Folkesundhedsvidenskab. Formelt tværfaglige fag tjener andre væsentlige funktioner end at levere et perspektiv på et emne, der behandles tværfagligt. Formel tværfaglighed medvirker til, at de studerende kan danne sig et indtryk af det enkelte fags kompleksitet og derved netop skærpe opmærksomheden på andre fag, samt kan få forskellige kompetencer. Når man gerne vil overskride noget, er det i en akademisk sammenhæng også væsentligt at vide, hvordan og på hvilke præmisser fagoverskridelsen finder sted. Anerkendelse af behovet for forskellige kvalitative og kvantitative grader af tværfaglighed kan være med til at skærpe opmærksomheden på dette.

\section{Folkesundhedsvidenskab - tværfaglig siden 1999}

På Institut for Folkesundhedsvidenskab, som hører under Det Sundhedsvidenskabelige Fakultet ved Københavns Universitet, har vi siden 1999 uddannet bachelorer og kandidater i Folkesundhedsvidenskab (FSV). Udgangspunktet for etableringen af den tværfaglige kandidatuddannelse i 1999 var, at viden om udviklingen i og indsatser for befolkningens sundhed kræver brug af forskellige faglige discipliner. To fakulteter er involveret i uddannelsen, det sundhedsvidenskabelige og det samfundsvidenskabelige, og underviserne har mange forskellige grunduddannelser (statistikere, læger, sociologer, historikere, antropologer, biokemikere mv.). Det gør uddannelsen mere mangfoldig end mange andre, at den rummer store elementer både af natur- og sundhedsvidenskab og af samfundsvidenskab. De fleste undervisere er ansat på Institut for Folkesundhedsvidenskab og laver folkesundhedsvidenskabelig forskning, som således er et mangehovedet dyr. Mangfoldigheden ses også i Bekendtgørelsens beskrivelse af uddannelsen: 
"§6. Bacheloruddannelsen består af 3 årsværk, der er fordelt på følgende fagområder:

1) Samfundsvidenskabelige fag.

2) Samfundsmedicinske fag.

3) Videnskabsteoretiske og forskningsmetodologiske fag.

4) Kommunikations- og adfxrdsfag.

5) Biomedicinske fag.

6) Valgfag, herunder projektarbejder." (Bekendtgørelse nr. 33 af 20.01.1999).

På trods af, at bekendtgørelsen beskriver 6 forskellige faggrupper, taler studerende og undervisere oftest kun om to: Sundhedsvidenskabelige, som også oftest omfatter kvantitative metodefag og har et positivistisk videnskabsteoretisk udgangspunkt, og samfundsvidenskabelige, som også rummer humanistiske fag og kvalitative metoder, som oftest har en konstruktivistisk epistemologi. Forskningssamarbejdet på instituttet ses også oftest inden for disse to faggrupper, sjældent mellem dem.

\section{Hvordan praktiseres tværfaglighed på uddannelsen i folkesundhedsvidenskab?}

Uddannelsens opbygning har skiftet undervejs. I starten fulgte man delvis lægeuddannelsens opbygning ved at lade de studerende begynde med en række monofag som økonomi, sociologi, statistik og etik og videnskabsteori. Tankegangen var, at det var nødvendigt at have forudsætninger inden for de fag, uddannelsen var en kombination af, før de studerende fik mere sammensatte fag. I 2009 gennemførte studienævnet en omfattende omorganisering af bacheloruddannelsen. Et princip, som vejledte ændringen, var, at de studerende skulle møde fag, som kunne kaldes folkesundhedsvidenskabelige allerede første semester. Derfor blev fagene Forebyggelse og sundhedsfremme og Sundhedsvæsenets struktur og funktion flyttet fra femte til første semester. Forventningen var, at det ville gøre det mere meningsfuldt først efter første semester at have fag, som ikke nødvendigvis er så tydeligt relaterede til Folkesundhedsvidenskab, fordi de studerende allerede havde fået en fornemmelse for, hvad Folkesundhedsvidenskab er. Et andet princip var, at de studerende så vidt muligt hvert semester skulle have både samfundsvidenskabelige og natur- eller sundhedsvidenskabeligt orienterede fag. Målet var, at hverken den ene eller den anden form for tænkning skulle opleves som fremmed.

Ambitionerne om at uddanne til tværfaglighed udtrykkes i kompetenceprofilen for bachelorer i Folkesundhedsvidenskab:

"Bachelorer i Folkesundhedsvidenskab har en bred og tværfaglig tilgang til sundhedsområdet, og uddannelsen er koncentreret om befolkningens sundhedstilstand, forebyggelse og sundhedsfremme samt sundheds- og socialvæsenets organisation og funktion. Desuden omfatter uddannelsen udvalgte adfxrds- og samfundsvidenskabelige discipliner samt en række sundhedsdiscipliner." (Kompetenceprofil for bacheloruddannelsen, 2009). 
Tværfagligheden beskrives forskelligt på bachelor- og kandidatuddannelsen. I bekendtgørelsen præciseres en bestemt vægtning af de forskellige faggrupper for bacheloruddannelsen, mens man om kandidatuddannelsen skriver, at fagene skal integreres. Det gælder i hvert fald metodefagene, som altså ikke her ses som knyttede til særlige fagtraditioner. (Bek $n r .33$ af 20.01.1999)

I studieordningernes beskrivelse af de enkelte studieelementer, hvilket på Folkesundhedsvidenskab indebærer 'kurser' og 'projektarbejde', gives yderligere indblik i, hvordan ambitionen om tværfaglighed gives konkrete udtryk.

\section{Kurser}

De studerende har både fag, som defineres monofagligt - fx sociologi, humanbiologi og statistik - og fag, som i hvert fald bindestregsmæssigt er tværfaglige: medicinsk sociologi, sundhedsøkonomi og sundhedspolitik. At det på bacheloruddannelsen i en vis grad handler om at opnå monofaglige indsigter, der senere kan bruges på en folkesundhedsvidenskabelig (tværfaglig) problemstilling, fremgår fx af kursusbeskrivelsen for faget sociologi:

"Faget omfatter en introduktion til almen sociologi med gennemgang af udvalgte klassiske og nyere teorier samt af sociologiens grundlæggende begreber og forklaringsmodeller med relevans for folkesundhedsvidenskabelige problemstillinger." (Studieordningen for bacheloruddannelsen, 2009, s. 7; 18).

Andre kurser fokuserer på et særligt tema, som kurserne i sundhedsvæsenets struktur og funktion, international sundhed og forebyggelse og sundhedsfremme. Nogle af disse fag bruger undervisere med forskellige videnskabsteoretiske udgangspunkter, fx International sundhed og Forebyggelse og sundhedsfremme. Andre fag har en eller to gennemgående undervisere med samme faglige ståsted, også flere af bindestregsfagene. Bindestregsfagene beskriver dog ikke sig selv som tværfaglige, det vil sige, der er ikke nogen eksplicit målsætning om, at faget skal integrere viden fra forskellige discipliner. Underviserne vil ofte komme med hver deres monofaglige tilgang og give de studerende deres vinkel på faget uden at forholde sig til andre underviseres undervisning.

Et særtræk ved uddannelsen i Folkesundhedsvidenskab er, at de studerende lærer meget metode. De introduceres allerede fra andet semester både til epidemiologi og kvalitative metoder. Uddannelsen er således også metodemæssigt tværfaglig. De kvantitativt orienterede metoder som statistik, epidemiologi og spørgeskemakonstruktion udgør hovedparten af metodeundervisningen målt i ECTS: 42,5 af de 60 ECTS. Selv om de studerende alle lærer at bruge forskellige metoder og har fag inden for så forskellige områder som humanbiologi og organisationsanalyse, vil mange af dem orientere sig mod enten den ene eller anden videnskabstradition. Det kan de 
gøre gennem valgfag, som udgør 70 ECTS på den samlede uddannelse, og projekter og speciale, som udgør andre 65 ECTS, men der er dog også rigtigt mange, som kombinerer det samfundsvidenskabelige og det sundhedsvidenskabelige, og det kvalitative og det kvantitative, i valgfag, projekter og specialer.

På kandidatuddannelsen skal de studerende tage 60 ECTS valgfag. Oftest består de valgfrie kandidatkurser $i$ en yderligere specialisering i en given disciplin som fx epidemiologi, sundhedsøkonomi eller sundhedspolitiske analyser. Andre valgfrie kurser er orienteret omkring et emne, som fx psykiatriske sygdomme eller reproduktiv sundhed, og hvor en funktionel tværfaglighed oftere forekommer. Det er vores indtryk, at disse kurser i varierende omfang inddrager viden fra forskellige typer af fag, men i og med at de fleste undervisere selv forsker inden for en enkelt disciplin, så er fagintegration ofte ikke et eksplicit fokus for undervisningen. Det er sjældent at undervisere fra forskellige fagligheder laver kurser sammen.

\section{Projektarbejde}

Om den første større opgave, de studerende skriver, førsteårs-projektet, står det, at "en tværfaglig tilgang (anses) at være en grundlæggende egenskab ved uddannelsen i folkesundhedsvidenskab og er således væsentlig at tilegne sig allerede på studiets 1. år" (Studieordningen for bacheloruddannelsen i Folkesundhedsvidenskab, 2009, s. 22). Hvad dette vil sige, ekspliciteres dog ikke ud over, at tre fag skal inddrages, og lignende udsagn findes ikke om andre dele af uddannelsen. Der er ikke krav om brug af flere fag til bachelorprojekt og kandidatspeciale men blot om, at der arbejdes med en folkesundhedsvidenskabelig problemstilling. At arbejde med en folkesundhedsvidenskabelig problemstilling behøver ikke indebære en tværfaglig tilgang. Retningslinjerne for bacheloruddannelsen vejleder desuden de studerende til at anvende en opgavestruktur fra et relevant fagområde fremfor at opfinde en fagoverskridende (Retningslinjer for bacheloruddannelsen i Folkesundhedsvidenskab, 2013, s. 12).

Uddannelsen i Folkesundhedsvidenskab har siden 1999 udviklet en stærk identitet, der blandt andet er baseret på den tværfaglige tilgang. De studerende ser sig selv og deres fag som én disciplin og bliver også opfattet sådan hos de aktører og institutioner, der kender uddannelsen. Opsummerende kan man sige, at tværfagligheden på uddannelsen i Folkesundhedsvidenskab fortrinsvis er tilrettelagt som formel tværfaglighed men med store muligheder for at praktisere funktionel tværfaglighed både i kurser og i projektarbejde. Det er i høj grad op til de enkelte studerende og lærere at vælge at gøre brug af disse muligheder.

\section{Er funktionel tværfaglighed en uopnåelig drøm?}

"It is like being able to use the whole box of tools more effectively because one knows just what each one is good for and capable of - and the different advantages, say, of a nail and a screw in different situations." (Foster, 1999, s. 359). 
Citatet af Foster opsummerer meget præcist den selvforståelse - og stolthed - der er knyttet til tværfagligheden på uddannelsen i Folkesundhedsvidenskab. Tværfagligheden gør det muligt at tilegne sig en bred værktøjskasse, så det samme værktøj ikke skal bruges til alle byggeprojekter. Muligheden for at lære at analysere fx udviklingen i befolkningens sundhed fra forskellige discipliner kommer dog også med nogle udfordringer. Den tværfaglige tilgang indebærer, at de studerende skal navigere mellem grundlæggende forskellige opfattelser af, hvordan verden er, og hvordan vi kan indsamle viden om den. For folkesundhedsvidenskabsstuderende betyder det, at de fra begyndelsen skal kunne operere med forskellige kriterier i forskellige sammenhænge. Ifølge Foster er mestringen af den tværfaglige værktøjskasse ikke blot en udfordring men en enorm opgave, kun de dygtigste studerende vil formå at håndtere:

"Certainly, when one recognizes the full range of both disciplines relevant to environmental higher education, and of the kinds of relevance which they deploy, it becomes much harder to persuade oneself that individual students ('every learner') can readily, with suitable help and guidance, span that range. [..] Can one really hope for appreciation of the methodological assumptions and limitations of disciplines right across the spectrum I have suggested?" (Foster, 1999, s. 365).

For Foster er løsningen, at funktionel tværfaglighed ikke skal praktiseres af den enkelte studerende men på et institutionelt niveau (Foster 1999, s. 365). Vi er enige med Foster i, at tværfaglighed indebærer en række udfordringer, men vi er ikke enige i, at løsningen er at opgive tværfaglige studerende. De fordele, der kommer af, at Folkesundhedsvidenskab er en tværfaglig uddannelse, opvejer i vores øjne de udfordringer, den indebærer. Folkesundhedsvidenskab har haft en meget lav arbejdsløshed siden de første færdiguddannede kandidater forlod uddannelsen i 2004 og ind til finanskrisen begyndte. Aftagerpanel og andre interessenter tilskriver tværfagligheden, og ikke mindst det brede metodekendskab, stor betydning for deres rekruttering af kandidater i Folkesundhedsvidenskab. Ligeledes har uddannelsen siden start haft en stor søgning af studerende og som konsekvens heraf en relativ høj adgangsgivende kvotient. Uddannelsen er således både i stand til at rekruttere dygtige studerende og afsætte dem på arbejdsmarkedet efter endt uddannelse. I vores øjne er der derfor andre steder at sætte ind end ved at nedprioritere tværfaglighed.

\section{Der er brug for en varieret og refleksiv tværfaglighed}

Diskussionen af de forskellige opfattelser af tværfaglighed samt analysen af de konkrete måder, som uddannelsen i Folkesundhedsvidenskab praktiserer tværfaglighed på, peger på en række muligheder for at styrke tværfagligheden. Muligheder som i bedste fald også vil tage bedre hånd om nogle af de udfordringer, som Foster peger på, og som derfor også kan være relevante i forhold til andre tværfaglige uddannel- 
sesprogrammer end Folkesundhedsvidenskab. For det første peger analysen på, at tværfaglighed ikke praktiseres på én måde. Der er nok en overvægt af formel tværfaglighed, men også væsentlige og betydelige muligheder for funktionel tværfaglighed gennem fx projektarbejdet. Det er en af uddannelsens styrker, at den ikke altid har fagoverskridende tværfaglighed som mål og i lige så høj grad prioriterer den formelle tværfaglighed eller flerfagligheden, hvor de studerende oparbejder kompetencer i forskellige discipliner, og hvor den interne koordination primært består af et fælles tema. Det har betydning for den eksisterende begrebsliggørelse af tværfaglighed. I vores øjne bør man i stedet for at betragte de forskellige kvalitative grader af tværfaglighed, som noget man skal vælge imellem eller værre endnu som en barriere for at opnå den eftertragtelige fagoverskridende tværfaglighed, anvende dem som en ressource. Det er faktisk en fordel for tværfaglige uddannelsesprogrammer at praktisere forskellige former for tværfaglighed til forskellige tidspunkter, da de studerende, for at opnå den omtalte værktøjskasse, både har behov for at træne fx statistiske kompetencer og for at træne og praktisere fagintegration. Derfor mener vi, der bør gøres op med den eksisterende norm om, at der findes gode og mindre gode former for tværfaglighed. I stedet for skal vi diskutere kvaliteterne ved og samspillet mellem forskellige former for tværfaglighed.

Det springende punkt i dette forslag er dog, at prioriteringen mellem forskellige kvalitative og kvantitative grader af tværfaglighed ikke skal foregå implicit men eksplicit. Som vist er der relativt lidt metakommunikation om den varierede tværfaglighed, som er fundamentet for uddannelsen. Det vil sige, at der ikke er kurser der specifikt adresserer, hvad det vil sige at være en tværfaglig disciplin, og hvilke muligheder og udfordringer det giver de studerende - og underviserne. En eksplicitering af disse er nødvendig for, at (de forskellige former for) tværfaglighed ikke overlades til de studerende alene at håndtere. Vi som undervisere skal ikke kun tage ansvar for at bidrage med vores eget fag eller viden. Det vil, efter vores vurdering, være en stor hjælp for de studerende, hvis de trænes i at forholde sig til forskellighederne mellem fagområderne ved, at der tales mere om dem i undervisningen. Det ville forudsætte, at også underviserne blev mere bevidste om, hvad forskellene består i, og helst også, at de udviklede større viden om og respekt for hinandens fagligheder i det omfang, disse ikke er til stede. Praktisk kunne det fx gøres ved i højere grad at gøre brug af redskaber og tiltag, der træner den studerende i at se sig selv og sit fag udefra (Amhøj, 2012). Som Foster påpeger, har tværfaglige studerende et særligt behov for at oparbejde refleksivitet og evnen til at analysere implicitte ontologiske og epistemologiske forskelle i egen og andres akademiske tænkning, hvis hammeren fra værktøjskassen ikke skal bruges på skruer og skruetrækkeren på søm. Et andet tiltag kunne derfor være at gøre tværfaglighed til et eksplicit læringsmål på uddannelsen og på relevante kurser, fremfor som nu primært at være en implicit praksis. Det kunne også indebære større tiltag som fx seminarer eller lignende, der diskuterede selve 
tværfagligheden og de muligheder og begrænsninger, den indebærer. I den nuværende praksis er det mestendels op til de studerende selv at identificere og eksplicitere de forskelle, som deres uddannelse indeholder. Det er der selvfølgelig en god læring i. Men som en del forskning allerede har vist, så lykkes tværfaglighed ofte bedst, hvis studerende og undervisere forsynes med de didaktiske redskaber, der er nødvendige for at praktisere den (jf. Davies \& Devlin, 2010).

\begin{abstract}
Annegrete Juul Nielsen er kandidat i Folkesundhedsvidenskab og tidligere studievejleder på uddannelsen. Hun underviser folkesundhedsvidenskabsstuderende i bl.a. globalisering af sundhedsteknologier og er VIP-repræsentant $i$ uddannelsens studienæon. I sin forskning er hun overordnet interesseret $i$, hvordan teknologier bliver til i og er med til at forme relationer mellem sundhedspolitik, organisatorisk praksis og patientliv. Aktuelt er hun særligt interesseret $i$ at forstå lokale implikationer af den stigende globalisering af sundheds- og velfardsteknologier.
\end{abstract}

Signild Vallgårda har været studieleder for uddannelsen i Folkesundhedsvidenskab i tre år og har undervist lægestuderende, MPH- og ph.d.-studerende og især folkesundhedsvidenskabsstuderende i bl.a. sundhedspolitik og sundhedsvæsenets struktur og funktion - også $i$ historisk perspektiv. Hendes forskning omhandler for tiden magtudøvelse $i$ forebyggelse og sundhedsfremme, betydningen af valg af sociale kategorier i forskning og politik og fedme som politisk problem.

\title{
Litteratur
}

Amhøj, C. B. (2012). At undervise på poststrukturalistisk - undervisning i organisation og ledelse som en selv-refleksiv iagttagelsesmaskine. Danmarks Universitetsprdagogiske Tidsskrift, 7(12).

Cook-Sather, A. \& Shore, E. (2007). Breaking the rule of discipline in interdisciplinarity: Redefining professors, students and staff as faculty. Journal of Research Practice, 3(2).

Davies, M. \& Devlin, M. (2010). Interdisciplinary higher education. In: M. Davies \& M. Devlin (2010). Interdisciplinary higher education: Perspectives and practicalities, 5, 2-28. Bingley: Emerald.

Foster, J. (1999). What price interdisciplinarity?: Crossing the curriculum in environmental higher education. Journal of Geography in Higher Education, 23(3), 358366.

Francks, D., Dale, P., Hindmarsh, R., Fellows, C., Buckridge, M. \& Cybinski, P. (2007). Interdisciplinary foundations: reflecting on interdisciplinarity and three decades of teaching and research at Griffith University, Australia. Studies in Higher Education, 32(2), 167-185

Ivanitskaya, L., Clark, D., Montgomery, G. \& Primeau, R. (2002). 3. Interdisciplinary Learning: Process and Outcomes. Innovative Higher Education. 27(2), 95-111.

Jensen, A., Troelsen, R. \& Zeuner, L. (2012). Fællesskab eller individualitet - om forskning og undervisning i et interdisciplinært universitetsmiljø. Dansk Universitetspædagogisk Tidsskrift,7(13). 
Klein, J. T. (1990). Interdisciplinarity: history, theory and practice. Detroit, MI: Wayne state University Press.

Københavns Universitet (2009). Indre marked på KU. Fælles spilleregler-fælles mål. København: Københavns Universitet.

Lattuca, L. R., Voight, L. J. \& Fath, K. Q. (2004). Does interdisciplinarity promote learning? Theoretical support and researchable questions. The Review of Higher Education, 28(1), 23-48.

Newell, W. H. (1994). Designing interdisciplinary courses. New Directions for Teaching and Learning, 58 [J .T. Klein \& W. G. Doty (Eds.): Interdisciplinary studies today.], 35-51.

Nielsen, V. O. (1996). Tværfaglighed og historie i folkeskolen. Vejle: Kroghs Forlag.

Spelt, E. J. H., Biemans, H. J. A., Tobi, H., Luning, P. A. \& Mulder, M. (2009). Teaching and learning in interdisciplinary higher education: A systematic review. Educational Psychology Review, 21, 365-378.

Youngblood, D. (2007). Interdisciplinary studies and the bridging disciplines: A matter of process. Journal of Research Practice, 3(2).

Østergaard, M. (2012) Fra forskning til fordybelse. Politiken 16. marts 2012

Materiale om uddannelsen $i$ folkesundhedsvidenskab ved Københavns Universitet

Bekendtgørelse om uddannelser i Folkesundhedsvidenskab. Undervisningsministeriet. Bekendtgørelse nr. 33 af 20.01.1999.

Kompetenceprofil for bacheloruddannelsen i Folkesundhedsvidenskab (2009). Studienævnet for Bachelor-Kandidatuddannelsen i Folkesundhedsvidenskab, Københavns Universitet.

Kompetenceprofil for kandidatuddannelsen i Folkesundhedsvidenskab (2009). Studienævnet for Bachelor-Kandidatuddannelsen i Folkesundhedsvidenskab, Københavns Universitet.

Retningslinjer for bacheloruddannelsen i Folkesundhedsvidenskab (2013). Studienævnet for Bachelor-Kandidatuddannelsen i Folkesundhedsvidenskab, Københavns Universitet.

Studieordningen for bacheloruddannelsen i Folkesundhedsvidenskab (2009). Studienævnet for Bachelor-Kandidatuddannelsen i Folkesundhedsvidenskab, Københavns Universitet.

Studieordningen for kandidatuddannelsen i Folkesundhedsvidenskab (2009). Studienævnet for Bachelor-Kandidatuddannelsen i Folkesundhedsvidenskab, Københavns Universitet. 